\title{
The prosodic properties of narrow information focus in Central Mexican Spanish: Pitch accents, de-emphasis and phrasing
}

\author{
Érika Mendoza Vázquez ${ }^{1}$, Rodrigo Gutiérrez-Bravo², Pedro Martín Butragueño ${ }^{2}$ \\ ${ }^{1}$ Instituto de Investigaciones Filológicas, UNAM, México \\ ${ }^{2}$ Centro de Estudios Lingüísticos y Literarios, El Colegio de México \\ emvazquez03@gmail.com ORCID: https://orcid.org/0000-0002-1832-8456 \\ rogutierrez@colmex.mx ORCID: https://orcid.org/0000-0003-2512-3771 \\ pmartin@colmex.mx ORCID: https://orcid.org/0000-0002-5181-7569
}

Enviado: 12/06/2020 Aceptado: 26/09/2020 Publicado en línea: 21/10/2021

Citation / Cómo citar este artículo: Érika Mendoza Vázquez, Rodrigo Gutiérrez-Bravo and Pedro Martín Butragueño (2020). The prosodic properties of narrow information focus in Central Mexican Spanish: Pitch accents, de-emphasis and phrasing. Loquens, 7(1), e069. https://doi.org/10.3989/loquens.2020.069

\begin{abstract}
This paper investigates the different prosodic strategies used for the marking of information focus in Central Mexican Spanish. For this purpose, we carried out a study of the prosodic properties of information focus both in clause final position and in situ. Our results show important differences when compared to other varieties of Spanish. Specifically, we observe that the most frequent accent signaling information focus is a monotonal pitch accent $\left(\mathrm{L}^{*}\right.$ or $\left.! \mathrm{H}^{*}\right)$ and not $\mathrm{L}+\mathrm{H}^{*}$. Furthermore, in many cases we observe that the pitch accent is not the only mechanism used to signal the focus: this is because we observe the presence of prosodic edges to the left of the focus, presumably functioning as an additional prosodic cue to identify it. Additionally, while we do not observe deaccenting of post-focal material, we do observe a sequence of non-rising forms (a flat pattern or "de-emphasis") following the pitch accent that signals an in situ information focus forced by the test. With respect to phonological phrasing, our results confirm the analysis in Prieto (2006), where it is proposed that syntactic constituency is not the primary factor that regulates phrasing in Spanish.
\end{abstract}

Keywords: Spanish, Mexican Spanish, focus, deaccenting, intonation, phrasing.

RESUMEN: Propiedades prosódicas del foco informativo estrecho en el español del centro de México: Acentos tonales, pérdida de prominencia y fraseo.- En este artículo se busca discutir los recursos prosódicos utilizados para la marcación del foco informativo en el español mexicano central. Para tal fin se elaboró un test diseñado para investigar las propiedades prosódicas del foco informativo en posición final e in situ. Nuestros resultados muestran algunas diferencias importantes entre este conjunto de datos y otras variedades del español. Específicamente, observamos que el acento tonal más frecuente se realiza con la forma monotonal $\left(\mathrm{L}^{*} \mathrm{o} ! \mathrm{H}^{*}\right)$, y no $\mathrm{L}+\mathrm{H}^{*}$. Más aún, en muchos casos observamos que el acento tonal no es el único mecanismo que se usa para marcar el foco. Concretamente, en nuestros resultados se observa la presencia de junturas y cesuras a la izquierda del constituyente focalizado, y que presumiblemente funcionan como una pista prosódica adicional para identificarlo. Por otra parte, no observamos desacentuación del material post-focal, sino una secuencia de formas no ascendentes (un patrón plano a modo de "pérdida de prominencia") que siguen el acento tonal que marca un foco informativo in situ, forzado por la prueba. Respecto al fraseo fonológico, los resultados confirman el análisis de Prieto (2006), que propone que la estructura sintáctica no es el factor principal que regula el fraseo en español.

Palabras clave: español, español mexicano, foco, desacentuación, entonación, fraseo. 


\section{INTRODUCTION}

In this paper we present the results of a reading task designed to investigate the prosodic properties of information focus in Central Mexican Spanish (CMS) ${ }^{1}$. This variety of Spanish has already been widely described, so our results should be considered within this specific frame of reference. Briefly, our results show the in this variety certain phenomena (i.e. pitch accents and de-emphasis) show a rather peculiar distribution, whereas others (phonological phrasing) do not differ as much from what has been reported in other varieties of Spanish. We report the results related to three different aspects of the investigation. The first aspect has to do with the pitch accents associated with information focus. Our results show that the pitch accent most frequently observed in this context in CMS is different from the one most frequently reported in several studies for other varieties of Spanish. This result is relevant from a comparative and dialectological perspective because in different varieties of Spanish, a $\mathrm{L}+\mathrm{H}^{*}$ accent associated with narrow focus statements has been reported (Prieto \& Roseano, 2010; Hualde \& Prieto, 2015), whereas in our results (below) we observe that the association between this pitch accent and information focus is not absolute, and in fact $\mathrm{L}+\mathrm{H}^{*}$ frequently alternates with a monotonal pitch accent $\left(\mathrm{L}^{*}\right.$ or $\left.! \mathrm{H}^{*}\right)$. According to Martín Butragueño \& Mendoza (2018, p. 142), in CMS "the association of a pitch accent with the nuclear syllable in a focus domain is a variable fact and not a categorical one. Non-rising pitch accents tend to be associated with $\mathrm{B}$ [road focus], and $\mathrm{L}+{ }_{i} \mathrm{H}^{*}$ with $\mathrm{N}$ [arrow focus], while $\mathrm{L}+\mathrm{H}^{*}$ has a neutral behavior. These tendencies are linked to probabilistic weights; however, it is important to take into consideration that any pitch accent can appear in any focus domain".

The second aspect we report has to do with the prosodic properties of post focal material in this variety of Spanish. Deaccenting and loss of prominence are relevant cues for determining the prosodic boundaries of focal domains. However, in our data we do not observe deaccenting of post-focal material, as is characteristic in languages like English. Instead we observe a sequence of non-rising forms (a flat pattern or "de-emphasis") following the pitch accent which signals an in situ information focus. In terms of information structure, this pattern without prominent forms presumably signals the same kind of given information that is characteristically deaccented in languages like English.

Lastly, we present our results with respect to phonological phrasing. Phonological phrasing in Spanish has received a considerable amount of attention in the last ten years, but many questions remain open. For instance,

\footnotetext{
${ }^{1}$ A previous version of our investigation was presented at the Hispanic Linguistics Symposium 2016, Georgetown University, Washington D.C. (October 7-9). We would like to thank Ingo Feldhausen, Silvio Cruschina, and the audiences at the XI Coloquio de Lingüistica en la ENAH and The 2016 Hispanic Linguistics Symposium for their valuable feedback and comments on earlier versions of this work. All errors that remain are of course our own.
}

whereas D'Imperio et al. (2005) report that in wide focus contexts Spanish has a very strong tendency to wrap the verb and the direct object (i.e. the VP: Truckenbrodt, 1999) into a single phonological phrase $\$ \mathrm{P}$ (irrespective of the branching or length of the direct object), Prieto (2006) reports that wrapping effects only take place when the direct object is non-branching. When this condition is not met, the subject and the verb form a single $\phi \mathrm{P}$ and the branching direct object constitutes by itself a single separate $\phi P$. This in turn indicates that prosodic binarity is the primary factor that regulates phrasing in Spanish, and not syntactic constituency. As will be seen in 4.3, our results confirm the analysis in Prieto (2006), since we observe no tendency for the VP to be wrapped into a single $\phi \mathrm{P}$ when the object shows double branching (i.e. when it is syntactically complex).

The paper is organized as follows. In section 2 we present a brief background of the three prosodic properties at hand as reported for other varieties of Spanish: the bulk of this background discussion has to do with phonological phrasing since this is an aspect of Spanish sentential prosody that remains particularly obscure up to this day. In section 3 we briefly lay out the methodology of our investigation. In section 4 we present our results and compare them with the results reported in works dealing with similar phenomena in other varieties of Spanish. In section 5 we discuss our results, and in section 6 we present our conclusions.

\section{BACKGROUND}

Regarding the pitch accents associated with foci in Central Mexican Spanish, de-la-Mota et al. (2010) have recorded a distinction between a $\mathrm{L}^{*} \mathrm{~L} \%$ pattern for broad focus statements, and $\mathrm{L}+\mathrm{H}^{*} \mathrm{~L} \%$ for narrow focus statements (see also Hoot, 2016). Martín Butragueño \& Mendoza (2018) also report the $\mathrm{L}+\mathrm{H}^{*}$ pitch accent, but they additionally report a $\mathrm{L}+{ }_{i} \mathrm{H}^{*}$ pitch accent: however, in their results $\mathrm{L}+\mathrm{H}^{*}$ is not clearly significant as a cue for focus, while $\mathrm{L}+{ }_{i} \mathrm{H}^{*}$ is more frequent with narrow focus. More importantly, they report cases of narrow focus where monotonal nuclear accents $\left(\mathrm{L}^{*}, ! \mathrm{H}^{*}\right)$ are observed. ${ }^{2}$ It should be noted that both in de-la-Mota et al. (2010) and Martín Butragueño \& Mendoza (2018), no distinction is made between information focus and contrastive focus; both are grouped together in the category of narrow focus statements. Lastly, in an analysis of intonational patterns of focus and word order, Kim \& Avelino (2003, p. 372) do consider different types of focus (broad focus, narrow focus and contrastive focus), but report for their Mexico City data that there is no correlation between pitch accent and focus type.

The $\mathrm{L}+\mathrm{H}^{*} \mathrm{~L} \%$ pattern has also been documented in other varieties of Spanish (Castilian, Cantabrian, Canarian, Venezuelan Andean, Dominican, Ecuadorian Andean, and Chilean Spanish) for declarative statements with narrow foci (Prieto \& Roseano, 2010). In other varieties of

\footnotetext{
${ }^{2}$ All the cases analyzed are in final position in the utterance.
} 
Spanish, such as Puerto Rican Spanish (San Juan), there is an alternation between the nuclear pitch accents $\mathrm{H}^{*}$ and $\mathrm{L}+\mathrm{H}^{*}$ associated with narrow focus statements (Armstrong, 2010), whereas in Argentinian Spanish, Gabriel et al. (2010) and Feldhausen et al. (2011) report the tritonal nuclear pitch accent $\mathrm{L}+\mathrm{H}^{*}+\mathrm{L}$. It should be noted that in these works, no distinction between information focus and contrastive focus is made either; again, both are grouped together as narrow focus statements. Vanrell \& Fernández-Soriano (2018), however, do analyze the syntactic and phonological realization of different types of narrow information and contrastive focus (specifically, focus on the subject and on the direct object) in European Spanish (Basque Spanish, Castilian and Canarian Spanish). These authors report a $\mathrm{L}+\mathrm{H}^{*}$ accent for both kinds of focus: as we will see, we obtained different results for information focus in Central Mexican Spanish.
In contrast with this, most aspects of phonological phrasing in Spanish remain obscure, and the results presented by different studies are often contradictory. There are essentially two ways of understanding the relation between phonological phrasing and syntactic structure. A number of works consider that syntactic constituency can have a bigger influence on phonological phrasing than prosodic considerations (Selkirk, 1995, 2011; Truckenbrodt, 1999 inter alia). Under this view, prosodic and syntactic constituents tend to coincide, as in (1). D'Imperio et al. (2005) report precisely this situation for Spanish and suggest that Spanish has a very strong tendency to wrap the verb and the direct object (the VP) into a single phonological phrase $(\phi P)$, irrespective of the branching or length of the direct object.

$$
\begin{aligned}
& \text { 1) a. Mario lavó los platos sucios. } \\
& \text { Mario wash.past.3sg the dishes dirty } \\
& \text { 'Mario washed the dirty dishes.' } \\
& \text { b. ( })_{\varphi \mathrm{P}}\left({ }_{\mathrm{TP}}\right. \text { [DP Mario] [VP lavó los platos sucios]]. }
\end{aligned}
$$

The other perspective proposes instead that phonological phrasing obeys primarily prosodic (and not syntactic) considerations (Ghini, 1993). For instance, according to prosodic binarity requirements, a phonological phrase is composed of two prosodic words, and Prieto (2006) reports precisely this situation for Spanish.
According to this proposal, the utterance in (1) is restructured as in (2). See also Downing \& Rialland (2017) for more considerations on the syntax-prosody interface and Martín Butragueño (forthcoming) for a constraint-based approach for Mexican Spanish data, considering syntactic and prosodic constraints.

$$
\text { 2) }{ }_{[\mathrm{TP}}[\mathrm{DP} \text { Mario] [VP lavó })_{\varphi \mathrm{P}}()_{\varphi \mathrm{P}}
$$

Lastly, post-focal material has also been considered. Ladd (2008, p. 231) highlights the accentual differences in "the treatment of repeated words or phrases, and more generally the treatment of 'given' information", and uses the term deaccenting in cases in which it would be expected that a "given" word would canonically bear the main accent, but where it actually does not. From a cross-linguistic perspective, Cruttenden (1993, apud Ladd, 2008, p. 232) reports differences between languages which show a tendency (or recurrence) to deaccent repeated material, like English, and languages that instead maintain the usual accentuation pattern, like Spanish. As noted, for instance, in Hualde \& Prieto (2015, p. 358), Spanish, like other Romance languages, typically shows "very little flexibility in the placement of the nuclear accent (or main phrasal stress), which almost invariably falls on the last content word, except for very marked cases of emphatic or contradictory focus". As a result of this, it has been pointed out that this accentuation pattern is maintained even in material which is given or has been mentioned previously in the discourse (Hualde, 2014, p. 266). Again, our results show that CMS does not behave quite exactly like this, and instead support other analyses of post-nuclear material in Spanish.

For instance, Spanish has been characterized as a language of strong macro-rhythm (Jun, 2014, p. 528) with a tendency to maintain the prominence of prosodic words in every position. Still, even though deaccenting is not observed in Spanish in the same way as it is in Germanic languages, it does show a process of pitch compression and tone reduction (cf. Face, 2002; Vanrell \& FernándezSoriano, 2018, for European Spanish). This process can be realized by means of moderate rising movements in the post focal material, less prominent than those registered in constituents that are not in focus. In extreme cases the tone is reduced in such a way that a rise in this part of the utterance is no longer realized (Face, 2002, pp. 48-49). In our data we do not observe deaccenting, strictly speaking. Rather, we observe a form of deemphasizing in which pitch accents are still present, but their prominence is reduced. 


\section{METHODOLOGY}

We designed a reading task considering foci of different lengths, constituency, and structural distribution. For instance, (3a) corresponds to a focused VP, whereas (3b) corresponds to a branching focused DP that is not in sentence-final position (see also Gabriel 2010 who reports non-final informational foci in Argentinian Spanish). This is relevant because the studies on phrasing in Spanish mentioned in the previous section consider only broad focus declarative statements.

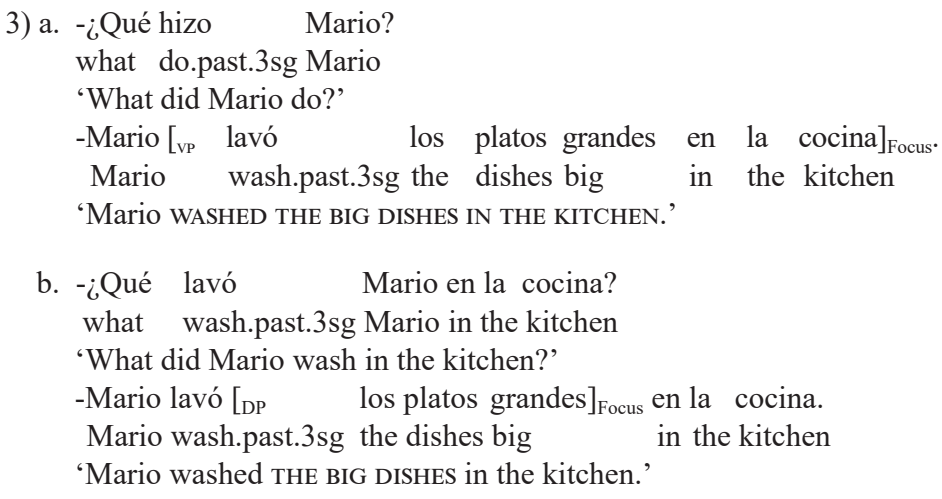

The materials used to test for the prosodic properties of in situ foci (i.e. foci that are not the last constituent of the sentence) were question-answer pairs like those in (4) and (5):

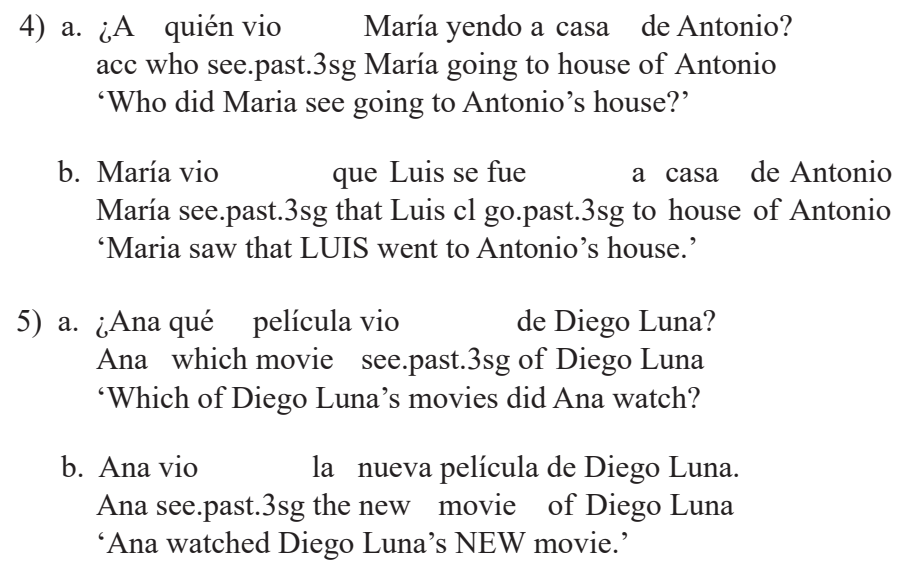

Six native speakers of Central Mexican Spanish were recorded -three females and three males- from two different age groups: four speakers ranging from 23 to 31 years of age and two older speakers (40 and 43 years, respectively). These speakers were all born in Mexico City, which is also currently their place of residence. All of the subjects have college education, but no knowledge or background in linguistics. The data we analyze are a sample of a larger set of 382 utterances where we tested for information focus and cleft sentences. The sample which we analyze in this paper is composed of 190 utterances, i.e. 31 utterances $\times 6$ subjects $=186$ utterances, plus an additional four utterances which were repeated during the reading task $(186+4=$ 190 utterances). In 124 of the 190 utterances the focus is sentence-final: the remaining 66 utterances are cases of in situ focus, i.e., non-canonical cases where the focus is not the final constituent of the sentence. 91 of the utterances correspond to simple clauses and 99 to complex clauses. In the design of the reading task we controlled for the word in focus so that it would always be a paroxytone word, and we also controlled for the sonority of the segments in the syllable bearing the nuclear stress. The reading task consisted of reading the answer of each of the question-answer pairs illustrated by the examples in (3) and (4). 
The stimuli input sentences were recorded three times with a female speaker of central Mexican Spanish. Subsequently, a validation was performed that consisted in asking seven judges to select the sentence of entry of each of the three series which sounded more natural. The test itself was conducted in a recording booth. A slide presentation was designed with the audio of the question and an answer to the question on the screen of a laptop computer; the answers on the slides had no punctuation marks whatsoever. Participants listened to the question and were asked to read the answers as naturally as possible (based on the context provided by the questions they had to listen to), with the answer appearing on the screen. Each participant listened to the question once and only the answer was displayed on the screen; optionally, the subject could hear the question a second time. A TASCAM model DR100-MK II recorder and a unidirectional Shure lapel microphone were used for recording the subject's reading of the answer to the question. ${ }^{3}$ The 31 questionanswer pairs testing for information focus were randomly intermingled with 31 pairs of sentences unrelated to information focus question-answer pairs, and which corresponded to an altogether different reading task.

The recorded utterances were transcribed using the Sp_ToBI labeling conventions (Estebas Vilaplana \& Prieto, 2008; Prieto \& Roseano, 2010). The prosodic structure of the utterance is represented with three different transcription tiers. The first tier is an orthographic tier where words are segmented by syllable. The second one is a tier of prosodic separation or break index, which uses a scale from 0 to 4 , in correspondence with the different levels of the prosodic hierarchy: a 0 value indicates the cohesion and absence of breaks between orthographic words, 1 indicates the edge of the phonological word, 2 signals the edge of the phonological phrase, 3 is used to signal the edge of a (non-final) intonational phrase, and 4 is used for the edge of the utterance. Lastly, the third tier is where pitch accents and boundary tones are marked. ${ }^{4}$ Our labeling further considers bi-tones for differences higher than 1.5 semitones $^{5}$ (st) (following the perception threshold proposed in Pamies et al., 2002, and Murrieta, 2016), whereas upsteps are associated with rises higher than 3 st (Martín Butragueño, 2011).

With respect to prosodic constituents, following Nespor \& Vogel (1986) and Gussenhoven (2004), we assume that the prosodic constituent that corresponds to the sentence is the utterance (see also Frota \& Vigário, 2018). Embedded in this domain, as the next level down in the prosodic hierarchy, is the intonational phrase (see Ladd, 2008; Beckman et al., 2002; and Martín Butragueño, 2019, forthcoming) which is in turn composed of phonological phrases, ${ }^{6}$ as illustrated in (6). Following Féry (2017) and Ito \& Mester (2012) we assume that there are no other relevant levels in the prosodic hierarchy (i.e. no intermediate phrases, for instance), but in contrast with these works we do not make use of recursion of any of these levels as part of our analysis. We further assume that these three different levels are always present in the prosodic representation of the sentence, i.e. none of these levels is ever absent from the prosodic representation. This last assumption, however, has no consequences for the analysis that follows.

\author{
utterance $U$ \\ intonational phrase 1 \\ phonological phrase $\varphi \mathrm{P}$
}

In the literature on phonological phrasing in Spanish there is no consensus about the acoustic cues that signal the edges of phonological phrases and other prosodic constituents: duration -final lengthening-, pitch reset, continuation rise or sustained pitch, pause, etc. (seesee Gorka et al., 2005; Prieto, 2006; Gabriel et al., 2011). For this purpose, in the analysis of the data that follows we have considered that the right edge of an intonational phrase is signaled by a notorious break (although not necessarily a pause) and specially by the realization of a distinct intonational contour (Nespor \& Vogel, 1986). Similarly, the right edge of a phonological phrase is identified by a continuation rise/rising

\footnotetext{
${ }^{3}$ The data was collected in the video recording booth of the Laboratorio de Estudios Fónicos (El Colegio de México).
}

movement or sustained pitch, which results in a kind of juncture. $^{7}$

\footnotetext{
${ }^{4}$ All transcriptions were done by the first author, and were later revised and discussed with the other two authors.

${ }^{5}$ For bi-tonal movements we measured the difference between the beginning and the end of the syllable. In the case of monotonal accents, the intensity peak within the syllable was taken as the reference to measure pitch.

${ }^{6}$ Although a thorough theoretical discussion of the nature of the phonological phrase as a prosodic constituent is beyond the scope of this paper, in our analysis we adopt it based on three considerations: i) constituent size (i.e. the accumulation of prosodic words) tends to result in breaks which do not necessarily have an autonomous contour (Martín Butragueño, forthcoming); ii) the resulting prosodic segments tend to coincide with syntactic constituents and focus domains, and; iii) the realization of this prosodic domain is observed in early stages of linguistic development (see Villalobos, 2020). As such, we take a break index 2 to be the explicit cue indicating the presence of a phonological phrase. In this respect, we depart from the proposal in Beckman et al., (2002) regarding the use of a break index 2.

${ }^{7}$ Other cues that have been considered in the literature for the identification of the edges of the phonological phrases are the blocking of some segmental processes, such as the spirantization of voiced plosives (Polo \& Elordieta, 2016) and, at a higher level, resyllabification.
} 


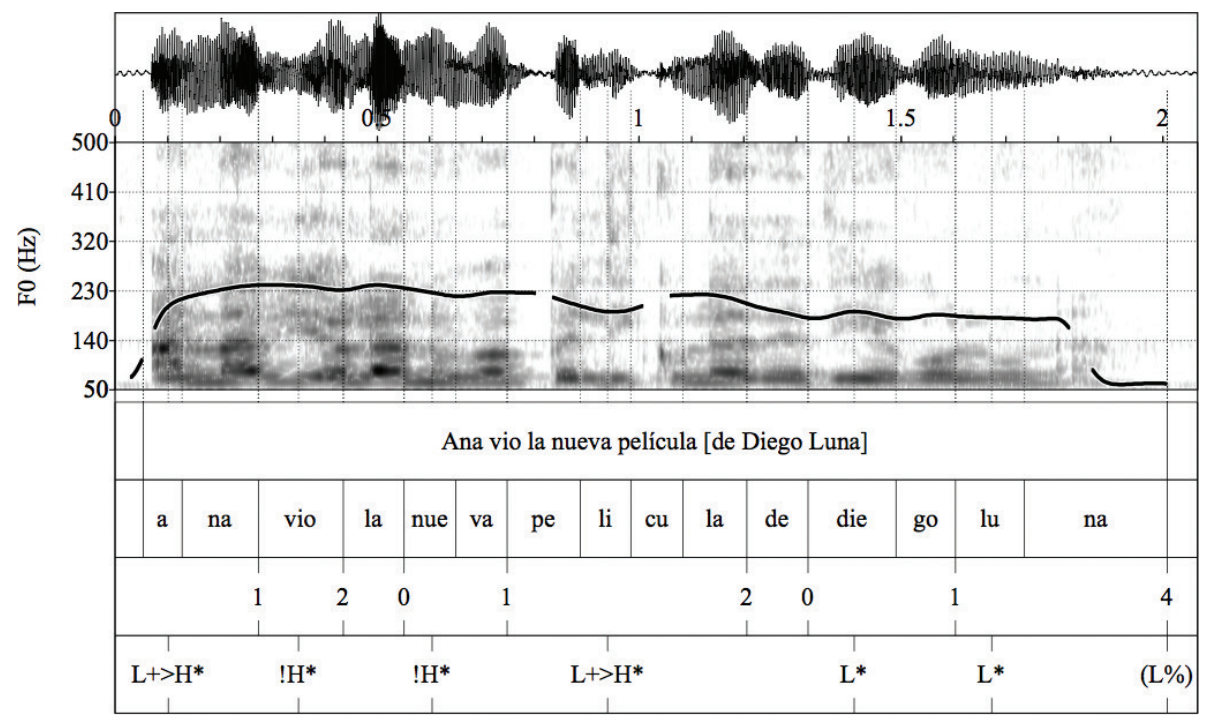

Figure 1: Waveform, spectrogram and F0 trace of the utterance (Ana vio) (la nueva película) (de Diego Luna), reply to ¿Ana de quién vió la nueva película?

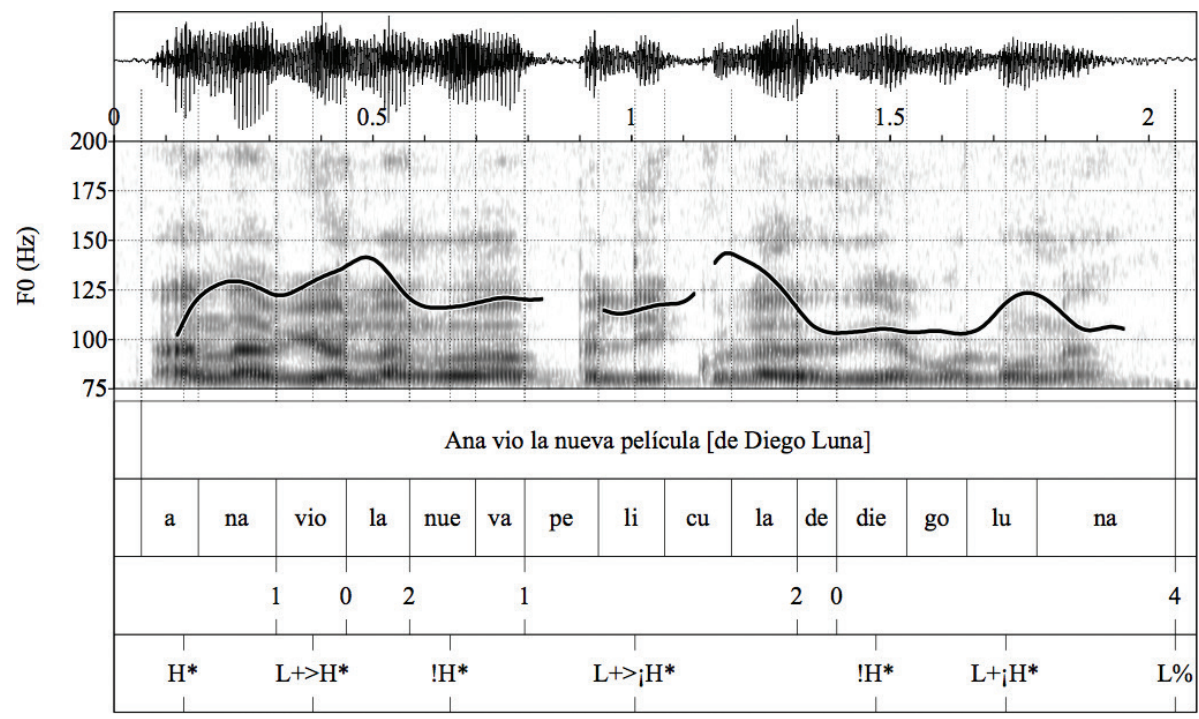

Figure 2: Waveform, spectrogram and F0 trace of the utterance (Ana vio la) (nueva película) (de Diego Luna), reply to ¿Ana de quién vió la nueva película?

\section{RESULTS}

\subsection{Pitch accents on the focus}

We registered cases where narrow information focus shows a $\mathrm{L}+\mathrm{H}^{*}$ bitonal pitch accent (as in Hualde $\&$ Prieto, 2015), but less frequently than those with a monotonal pitch accent $\left(! \mathrm{H}^{*}\right.$ or $\left.\mathrm{L}^{*}\right)$. Out of a total of 190 utterances, only $30 \%(\mathrm{~N}=57)$ show a $\mathrm{L}+(\mathrm{i}) \mathrm{H}^{*}$ rising pitch accent. In contrast, $31.6 \%(\mathrm{~N}=60)$ displayed the non-rising pitch accent ! $\mathrm{H}^{*}$, and $38.4 \%(\mathrm{~N}=73)$ correspond to $\mathrm{L}^{*}$, a falling contour or voiceless sounds in final position. Figure 1 shows a $\mathrm{L}^{*}$ nuclear accent, where the information focus is in its canonical final position. ${ }^{8}$ It is observed that the two prosodic words that integrate the last phrase, (of Diego Luna), are realized with a monotonal pitch accent, in contrast to the prenuclear material, which shows a bitonal pitch accent. The $\mathrm{L}^{*}$ pitch accent in "Diego" has a difference of 2.5 semitones when compared to the preceding bi-tonal accent. The falling movement continues in the monotonal $\mathrm{L}^{*}$ nuclear accent with a movement of 1.5 st. The $\mathrm{L} \%$ boundary tone in parentheses indicates vowel weakening

\footnotetext{
${ }^{8}$ For all figures, in the pitch settings of the Praat window we consider the parameters in $\mathrm{Hz}$ for female $(75-500 \mathrm{~Hz})$ and male $(75-250 \mathrm{~Hz})$ voice ranges. In some cases, a reduction was made in the scale to adapt it to the voice range of the speaker. Figures were made by Welby's script (2003, modified in 2009).
} 


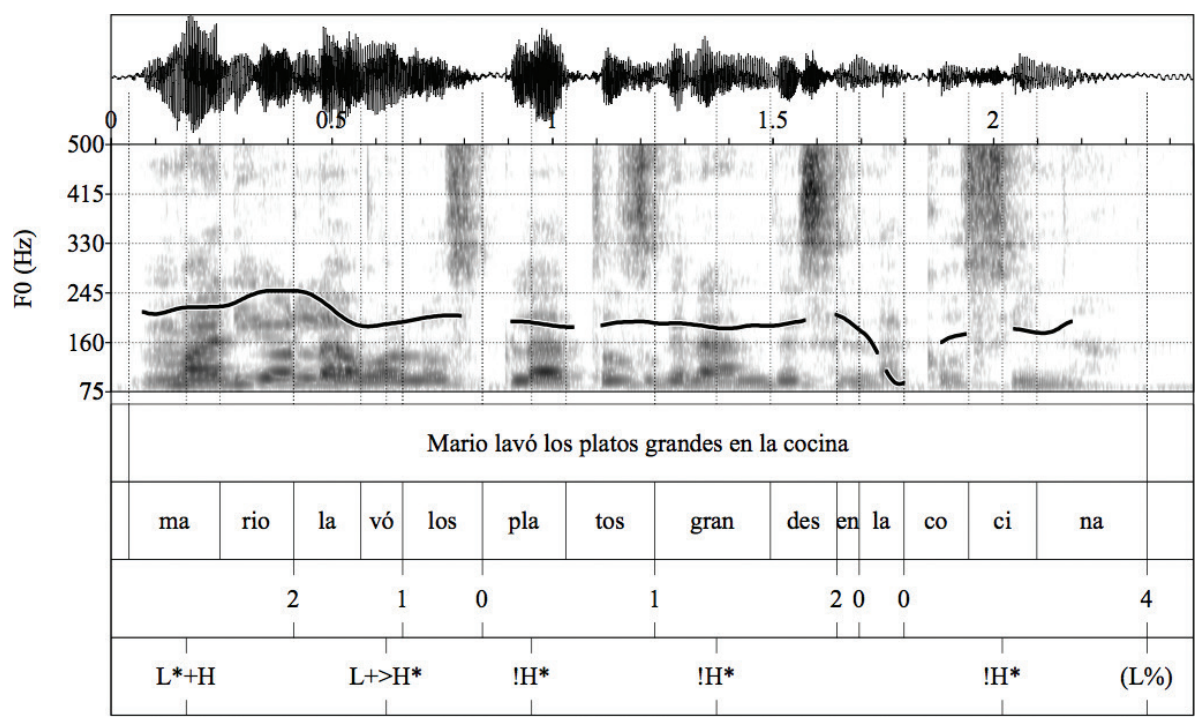

Figure 3: Waveform, spectrogram and F0 trace of the utterance (Mario) (lavó los platos grandes) (en la cocina), reply to ¿Qué hizo Mario?

in the final syllable. Compare this with Figure 2, with the nuclear configuration $\mathrm{L}+{ }_{i} \mathrm{H}^{*} \mathrm{~L} \%$. In this utterance, a decrease of 3 semitones occurs at the edge of the phrase (nueva película), followed by a monotonal pitch accent that precedes the nuclear pitch accent $\mathrm{L}+{ }_{i} \mathrm{H}^{*}$, with a rise of 3.5 semitones. Thus, we observe two distinct configurations characteristically associated with information focus: $\mathrm{L}^{*} \mathrm{~L} \%$ (Figure 1) and $\mathrm{L}+{ }_{i} \mathrm{H}^{*} \mathrm{~L} \%$ (Figure 2 ).

Figure 3 illustrates an example of the monotonal nuclear pitch accent ! $\mathrm{H}^{*}$. After the tonal peak alignment of the word "lavó", the following pitch accent shows a fall of 1.3 st, while the next pitch accents show a difference of $0.4 \mathrm{st}$ and $0.5 \mathrm{st}$, respectively. In this way, the utterance is produced with a sequence of monotonal accents. This pattern is thus different when compared to the falling configuration $\mathrm{L} * \mathrm{~L} \%$.

Lastly, a relevant point has to do with the marking of the left edge of the clause-final focus. In the three examples presented above it is possible to observe a falling movement of the F0 which marks the prosodic domain of the phonological phrase that precedes the constituent in focus. As will be discussed in detail in what follows, our data indicates that there is an interaction between the realization of a pitch accent and the marking of the left edge, such that they appear to be simultaneous cues for marking the focus.

\subsection{In-situ foci: pitch accents and post-focal material}

We now present our results with respect to the prosodic properties of in situ foci (i.e. foci that are not the last constituent of the sentence), and of the material that follows the focus in these cases.

In situ foci mostly show the monotonal ! $\mathrm{H}^{*}$ pitch accent, in $54 \%(\mathrm{~N}=36)$ of 66 utterances; in contrast, in situ foci showed the $\mathrm{L}+\mathrm{H}^{*}$ bitonal pitch accent in just $31 \%(\mathrm{~N}=20)$ of the cases we registered, whereas in $15 \%$ of all utterances $(\mathrm{N}=10)$ the focus bears the $\mathrm{L}^{*}$ pitch accent. It is worth mentioning that we also observed that when the focus shows a rising pitch accent, there is a tendency to introduce a non-final intonational-phrase boundary tone, i.e., it is possible to observe an intonational contour and additionally the introduction of a pause immediately after the focus, as in Figure 4. This intonational contour and pause insertion signals an intonational phrase (1) prosodic domain, and consequently leaves the focused constituent in a natural nuclear position, thus fulfilling the requirement that maximum prosodic prominence in Spanish should be rightmost.

Figure 5 is slightly different. In this case it is plausible to postulate the presence of an intonational phrase boundary after nueva because of the sustained movement and intonational contour observed. ${ }^{9}$ We also registered cases where there is no pause, but the intonational contours associated with boundaries could similarly indicate an intonational phrase boundary (a level 3 break index in Sp_ToBI).

Lastly, consider the prosodic properties of post-focal material in these cases. Our data shows a tendency where post-focal material is realized as a whole flat pattern, without inflections or prominent movements. In a sample of 66 utterances, $(71 \%$, i.e. 47 cases) the post-focal phonic material was realized with monotonal accents, whereas bitonal accents were registered in the remaining utterances $(29 \%, 19$ cases $)$. As can be seen in Figure 5, we observe that in these cases the intonational movement following the focus is maintained at the same level, without a low nuclear configuration, that is $! \mathrm{H}^{*} \mathrm{~L} \% / \mathrm{M} \%$ (i.e., it is realized as a medium or sustained tone of the preceding ! H* nuclear accent). ${ }^{10}$ This flat pattern can be described as a "loss of prominence" or "de-emphasis", in contrast with complete deaccenting. In our data, duration and vowel quality are preserved in postfocal material, accompanied

\footnotetext{
${ }^{9}$ Figures 4 and 5 are cases where the pitch accent on the focus is $\mathrm{L}+\mathrm{H}^{*}$, and not the more frequent $! \mathrm{H}^{*}$ accent. Note the moderate rise of 2 st. in the focus in Figure 5.

${ }^{10}$ As previously mentioned, in Estebas Vilaplana \& Prieto (2008: 276) the notation $\mathrm{M} \%$ is used to represent a medium or sustained tone. This movement is equivalent to the notation $! \mathrm{H} \%$ in the revision by Hualde \& Prieto (2015).
} 


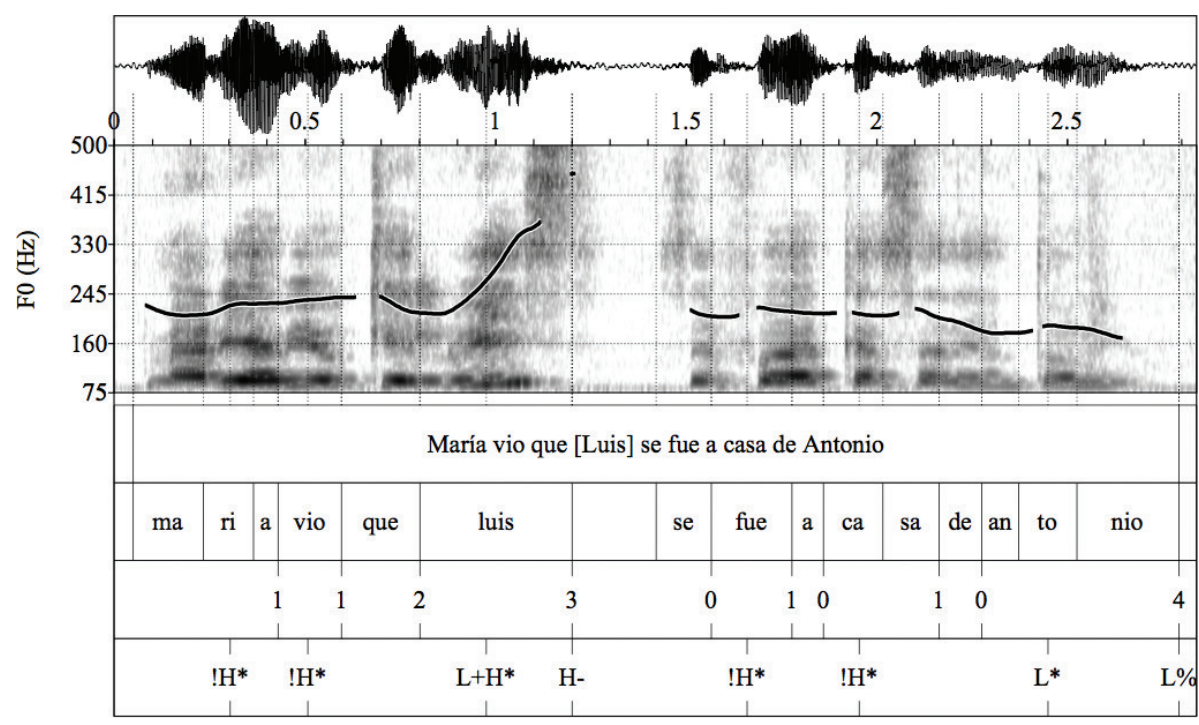

Figure 4: Waveform, spectrogram and F0 trace of the utterance (María vio que) (Luis) (se fue a casa de Antonio), reply to María ¿a quién vio que se fue a casa de Antonio?

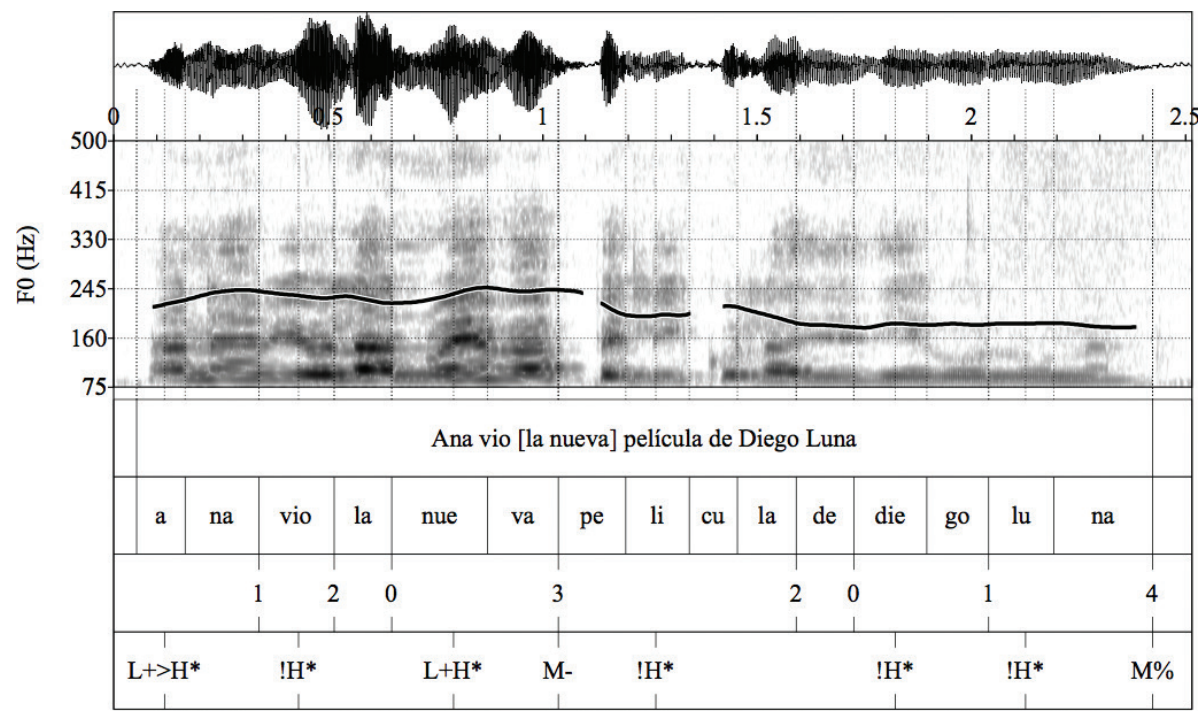

Figure 5: Waveform, spectrogram and F0 trace of the utterance (Ana vio) (la nueva) (película) (de Diego Luna), reply to ¿Ana qué película vio de Diego Luna?’

by sequences of monotonal accents. In addition, in some cases, it is observed that the ! $\mathrm{H}^{*}$ accents show a small rising, less than 1 semitone.

\subsection{Phrasing}

Finally, we present our results with respect to phonological phrasing. Specifically, we present our results for two different focus domains: focus on the direct object, and focus on the VP.

\subsubsection{Focused direct objects}

Consider now the two different views of phonological phrasing laid out in $\$ 2$. In the questionanswer pair where the question requires the direct object of the answer to be the focus, the syntactic approach to phrasing requires the direct object (or the whole of the VP that contains it) to be "wrapped" (Truckenbrodt, 1999) in a single prosodic constituent, as illustrated in (7) 


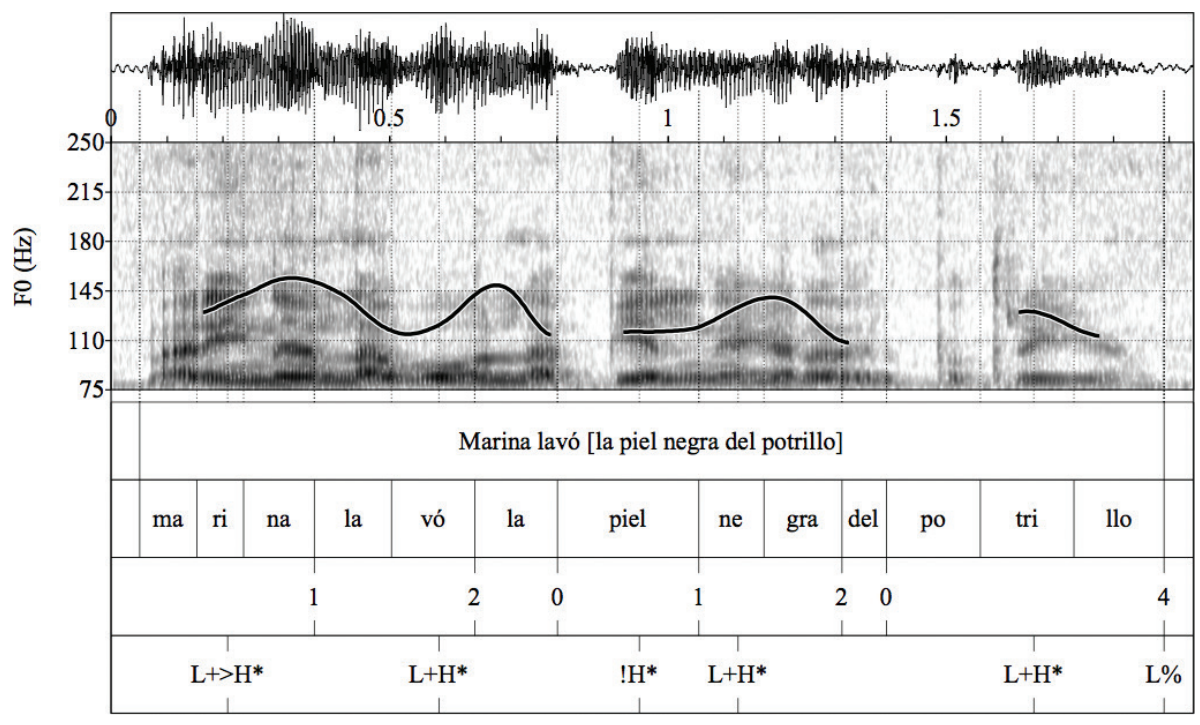

Figure 6: Waveform, spectrogram and F0 trace of the utterance (Marina lavó) (la piel negra) (del potrillo), reply to ¿Qué lavó Marina?

\author{
7) a. ¿Qué lavó Marina? \\ what wash.past.3sg Marina \\ 'What did Marina wash?' \\ b. Marina [vp lavó [DP la piel negra del potrillo]]. \\ Marina wash.past.3sg the skin black of.the stallion \\ 'Marina washed the black skin of the stallion.'
}

This is far from being the typical situation observed in our results for focused direct objects. Instead, we observe here that CMS data most frequently does not show wrapping effects, even for the focused constituent itself. For instance, the two most frequent patterns of phonological phrasing for (7) are instead the ones schematized in (8)

8) a. ((Marina lavó $)_{2}$ (la piel negra $)_{2}$ (del potrillo)

b. ((Marina lavó la $)_{2}$ (piel negra $)_{2}$ (del potrillo))

Here the double branching DP is divided into two phonological phrases: (a) the first one includes the head noun of the direct object and the adjective, and (b) the second one includes the PP embedded in the DP. More importantly, the verb in this case forms a phonological phrase with the subject. This rules out the possibility that what is being observed here is that the whole VP and the direct object do form a single prosodic constituent which simply happens to be larger than a phonological phrase. This can be seen in Figure 6. In (Marina lavó) a progressive rising is observed along the tonic syllable that extends towards the post-tonic. However, it is not perceived as a displacement to the post tonic, but as a continuation rise: the rising movement to the tonal peak is 5.4 semitones. In the case of the constituent (la piel negra), we consider the fall of 4.5 semitones aligned with the phrase to be the relevant prosodic cue. In some cases, intonational contours with a value greater than 3 semitones, associated with boundaries, may indicate a type of level 3 break index (in Sp_ToBI).

We further observe that in the large majority of cases, if an utterance ends with a PP, the PP forms its own phonological phrase, as in Figure 6, which is also reported in Prieto (2006). This turned out to be independent of (a) whether the PP is binary (i.e. de Diego Luna, 'of Diego Luna') or not (i.e. del potrillo, 'of the stallion'); (b) whether the PP corresponds or not to the focus of the utterance; and (c) whether the PP is embedded directly under the VP, or if it is embedded within a DP.

Now, wrapping effects are typically reported for VPs and not just DPs (even when the focus inside the VP is actually smaller than the VP itself). As such it is important to confirm if these same results are observed when the whole VP is in focus, and not only with focused direct objects. Our results indeed confirm these results.

\subsubsection{Focused matrix VPs in simple clauses}

We observe that focused matrix VPs in simple clauses with branching direct objects and PPs are not usually wrapped into a single $\phi \mathrm{P}$ : rather, the most frequent phrasing pattern is the one in Figure 7 (i.e. the first row of 


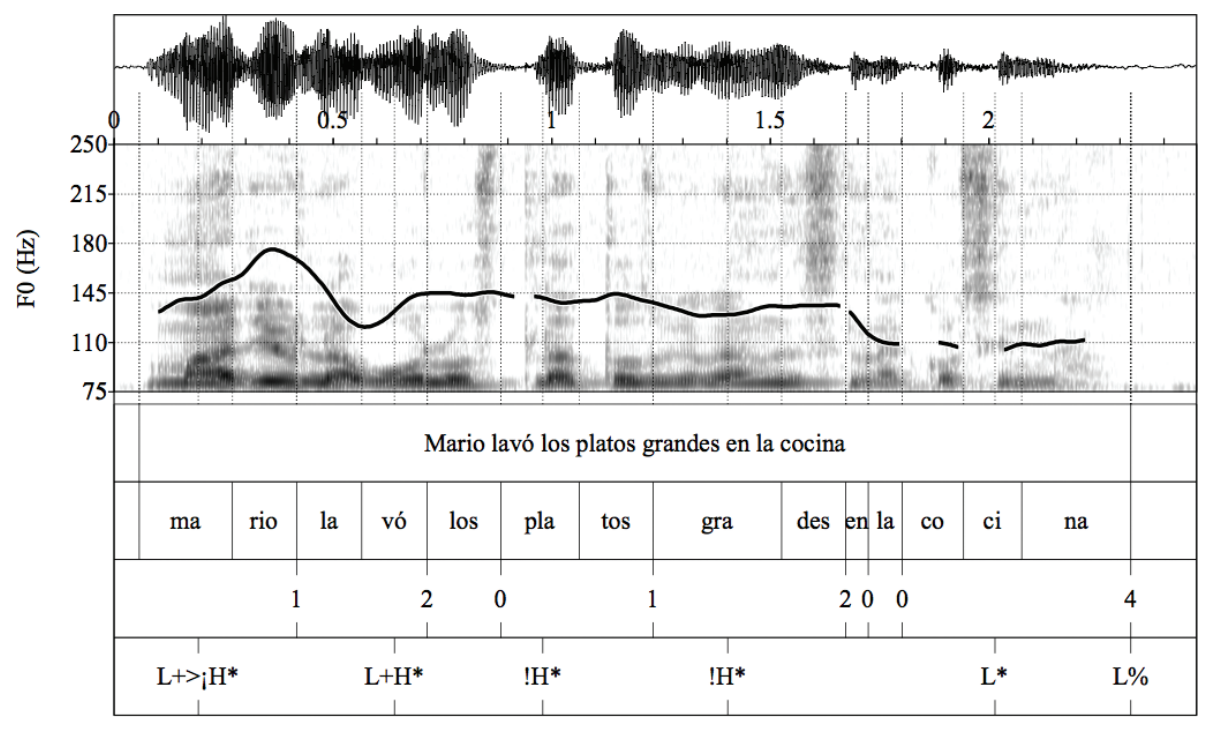

Figure 7: Waveform, spectrogram and F0 trace of the utterance (Mario lavó) (los platos grandes) (en la cocina), reply to ¿Qué hizo Mario?

Table 1: Phrasing of focused matrix VPs in simple clauses.

\begin{tabular}{lcc}
\hline & N & \% \\
\hline (SV)(O) (PP)/(S V D)(NP) (PP) & 6 & $33 \%$ \\
(S)(VO) (PP) / (V NP) (PP) & 5 & $28 \%$ \\
(S) (VP) & 4 & $22 \%$ \\
(S) (V D Adj) (N) (PP) & 2 & $11 \%$ \\
(S) (V D) (N Adj) (PP) & 1 & $6 \%$ \\
\hline
\end{tabular}

Table 1). In this figure, which corresponds to the case of VP focus in (3a), the constituents of the VP are phrased into three different $\phi P s$ : the verb is phrased together with the subject, and the branching direct object and the PP adjunct are phrased into separate $\phi P s$.

Observe that in this case binarity also appears to play an important role in phrasing. Hence the first $\phi P$ is composed of two phonological words, the subject and a verb, and the same situation is observed with the second phonological phrase, composed of the prosodic words corresponding to the noun and the adjective that modifies it. ${ }^{11}$ Just as in the case of focused direct objects, the utterance-final PP almost always forms its own $\phi P(78 \%)$. Our total results for focused matrix VPs in simple clauses are shown in Table 1.

It is important to note that this rather large variety of phrasing patterns is not an unexpected result. Inter-speaker variation with respect prosodic phrasing has recently been reported in numerous works; for Spanish in particular, see

\footnotetext{
${ }^{11}$ The definite article that modifies the noun is also most frequently part of this second $\phi P$, although we did register some cases where it is phrased with the verb in the first $\phi \mathrm{P}$ (in the first row of Table 1): see also (8b). Observe that this particular pattern would be extremely difficult to account for in the syntactic approach to phrasing.
}

Feldhausen (2016) and Feldhausen \& Lausecker (2018). More importantly, in spite of this inter-speaker variation, the following tendencies can be observed in these results. While subjects most often form their own $\phi \mathrm{P}(67 \%$ of all cases) it is certainly not the case that the VP behaves similarly (cf. §2). The VP corresponds to a single $\phi \mathrm{P}$ in only $22 \%$ of all cases (the third row of Table 1 ). In all other instances, the components of the VP are grouped into multiple $\phi P s$ ( $78 \%$ of all cases). In fact, it is not even the case that the verb and its direct object most frequently are found in the same $\phi \mathrm{P}$, since this only occurs in $50 \%$ of all cases (second and third rows of Table 1). Since it is unquestionable that the relation between the verb and its direct object is one of the tightest head-complement relations, these data are problematic for the hypothesis that prosodic domains in Spanish show a tendency to match syntactic domains and constituency (i.e. the syntactic approach to phrasing).

\subsubsection{Focused matrix VPs in complex clauses}

An interesting result of our investigation is that phrasing patterns of focused VPs are strikingly different in complex sentences like those in (4b). In these cases, the VP is much longer, since the subordinate complement clause is a part of it. Still, under a thoroughly strict interpretation of the syntactic approach to phrasing, we would nevertheless expect the VP to form a single $\phi P$ (at least sometimes). However, we registered no cases where the matrix VP corresponds to a single $\phi P$. Our complete results for these structures are shown in Table 2. As can be observed in these results, there is a much larger variety of phrasing patterns in these complex structures, a fact for which we have no explanation at this point, but which should be the subject of future research. Also, while it is clear that syntactic constituency (of the matrix VP: bottom row of 
Table 2: Phrasing of focused matrix VPs in complex clauses.

\begin{tabular}{lcc}
\hline & N & \% \\
\hline (S) (V Comp S) (VP) & 5 & $27 \%$ \\
(SV) (Comp S) (VP) & 4 & $22 \%$ \\
(SV) (CP) & 4 & $22 \%$ \\
(SV) (Comp S V PP) (PP) / & 2 & $11 \%$ \\
(SV Comp) (S V PP) (PP) & & \\
(SV Comp S) (VP) & 1 & $6 \%$ \\
(S) (V Comp NP) (PP VP) & 1 & $6 \%$ \\
(SV) (Comp S V PP P) (DP) & 1 & $6 \%$ \\
(S) (VP) & 0 & $0 \%$ \\
\hline
\end{tabular}

Table 3: Phrasing of focused subordinate VPs in complex clauses.

\begin{tabular}{|c|c|c|}
\hline & $\mathbf{N}$ & $\%$ \\
\hline $\begin{array}{l}\ldots(\text { Comp S) }(\mathrm{VP}) / \ldots(\mathrm{V} \text { Comp S) }(\mathrm{VP}) / \\
(\mathrm{S} \text { V Comp S) (VP) }\end{array}$ & 9 & $75 \%$ \\
\hline$\ldots($ Comp S) (V D N) (Adj) & 2 & $17 \%$ \\
\hline$\ldots($ V Comp S VP) & 1 & $8 \%$ \\
\hline
\end{tabular}

Table 2) is not playing any role in the phrasing patterns observed, it is also true that prosodic binarity does not play the clear role it does in matrix VPs in simple clauses, something which should also be addressed in a future investigation.

In spite of the larger variety of phrasing patterns, our results do show some clear tendencies. The most salient one is that the matrix subject forms a $\phi P$ with the matrix verb (either by itself or with other additional post verbal elements) in $67 \%$ of all cases, versus $33 \%$ in Table 1 , a pattern also reported for similar complex syntactic structures in Peninsular Spanish in Feldhausen (2016). The embedded subject also show an interesting behavior. In $55 \%$ of all cases we identify the right edge of a $\phi \mathrm{P}$ immediately after it, but, with respect to the left edge of its prosodic constituent, we observe that the subject is almost always found in the same $\phi \mathrm{P}$ as the complementizer of the embedded clause. In these cases, we observe that the embedded subject forms this $\phi P$ with the complementizer by itself (second row of Table 2) or with additional material from the matrix clause (first and fifth rows of Table 2). In fact, in stark contrast to the tendency observed for matrix subjects in Table 1, we registered no cases where the embedded subject forms its own $\phi P$. Lastly, it is also interesting that, even though the matrix VP never forms a $\phi \mathrm{P}$ by itself in these cases, the embedded VP shows a stronger tendency to form a $\phi \mathrm{P}$ by itself $(55 \%)$ than matrix VPs in Table $1(22 \%)$. This shows a clear correlation with the phrasing patterns observed for the embedded subject: in every case that the embedded VP forms a $\phi \mathrm{P}$ by itself, the embedded subject in turn forms a $\phi \mathrm{P}$ with either the complementizer by itself, or with additional material to the left of the complementizer (first, second and third rows of Table 2), which is consistent with the result that the embedded subject never forms a $\phi \mathrm{P}$ by itself.

\subsubsection{Focused VPs in subordinate clauses}

The third and last kind of focused VP that was part of our study were focused VPs in subordinate clauses (i.e. the VP of the subordinate clause). The focused VPs in the sentences we designed for this purpose had a single branching or non-branching direct object or complement, and there was no utterance-final PP in these sentences. This is the one case where our results did show clear evidence of wrapping effects, as can be observed in Table 3 .

As can be seen in these results, when the embedded VP is the focus, it forms its own $\phi \mathrm{P}$ in $75 \%$ of all cases. Additionally, and further confirming the results in Table 2, we observe no cases where the embedded subject forms its own $\phi \mathrm{P}^{12}$

Overall, when the results of the three different kinds of VPs are tallied together, though, we observe that VPs form their own $\phi P$ only in $27 \%$ of the cases, again contrary to what would be expected under the syntactic approach to phrasing. Syntactic constituency would appear to be a factor regulating phrasing when the verb and a non-branching or single branching direct object are the only constituents in the VP (as in Table 3). But this ceases to be the case when the VP is structurally more complex: double branching of the direct object, utterance final adjunct PPs, and complement clauses embedded in the VP, all contribute to the VP being mapped into two or more $\phi P s$.

\section{DISCUSSION}

\subsection{Pitch accents on the focus}

In the data we observe that information focus is signaled with three different pitch accents, the monotonal $\mathrm{L}^{*}$ and $! \mathrm{H}^{*}$ and the bitonal pitch accent $\mathrm{L}+(\mathrm{i}) \mathrm{H}^{*}$. The frequency of appearance of these different pitch accents is shown in Table 4. Observe that the realization of the pitch accent with respect to the position of the focus is statistically significant $(p=.000)$.

It is noteworthy that monotonal forms are more frequent when compared to the bi-tonal $\mathrm{L}+\mathrm{H}^{*}$ accent. (Although it could be considered that, even though the ! H* accent does not show a rising movement, it still shows a high tonal level, since it stays within the range of the former pitch accent). Interestingly, the presence of monotonal forms in turn indicates that the prominent $\mathrm{L}+\mathrm{H}^{*}$ pitch accent is not the only cue for focus marking in

\footnotetext{
${ }^{12}$ It is noteworthy that similar results (although for a different type of complex clause, and with a lower frequency of occurrence) are reported for Peruvian Spanish in Feldhausen \& Lausecker (2018).
} 
Table 4: Pitch accents and focus position

\begin{tabular}{lccc}
\hline Pitch accent & $\begin{array}{c}\text { final focus } \\
(\mathbf{N}=\mathbf{1 2 4})\end{array}$ & $\begin{array}{c}\text { in-situ focus } \\
(\mathbf{N}=\mathbf{6 6})\end{array}$ & Total \\
\hline $\mathrm{L}^{*}$ & $63(51 \%)$ & $10(15 \%)$ & $73(38 \%)$ \\
$! \mathrm{H}^{*}$ & $24(19 \%)$ & $36(55 \%)$ & $60(32 \%)$ \\
$\mathrm{L}+\mathrm{H}^{*} / \mathrm{L}+{ }_{i} \mathrm{H}^{*}$ & $37(30 \%)$ & $20(30 \%)$ & $57(30 \%)$ \\
\hline
\end{tabular}

$\chi^{2}(2$ df., $N=190)=31.147, p=.000$

Table 5: Marking of left edge and focus position

\begin{tabular}{lccr}
\hline Position & $\begin{array}{c}\text { Left edge } \\
\text { marked }\end{array}$ & No marking & \multicolumn{1}{c}{ Total } \\
\hline Final focus & $70(74 \%)$ & $54(57 \%)$ & $124(65 \%)$ \\
in-situ focus & $25(26 \%)$ & $41(43 \%)$ & $66(35 \%)$ \\
& 95 & 95 & $190(100 \%)$ \\
\hline
\end{tabular}

$\chi 2(1 \mathrm{df}, N=190)=5.943, p=.015$

CSM: this is because we registered cases where junctures (i.e. phonological or intonational phrases) are found in the edges preceding the focus, thus providing an additional cue for its identification. Table 5 illustrates the presence of these left edges with respect to the two different focus positions considered in our study.

As can be seen in this table, foci in clause final position show a greater tendency to have their left edge marked. This tendency is confirmed with the results of the $\chi 2$ test and the Fisher's exact test (.022 two-tailed and .011 onetailed). The marking of the left edge of the clause final foci may explain the frequent appearance of monotonal accents in that position. As such, it could be seen as a compensatory strategy, in which prosodic marking of a focused constituent shows both a local prosodic cue, the pitch accent, and a non-local one, the marking of its left edge.

\subsection{In situ foci: pitch accents and post-focal material}

Whereas post-focal constituents characteristically show deaccenting in languages like English (Selkirk, 1995; Ladd, 2008), this is not what is observed in Spanish, and our results for CMS confirm this observation. Specifically, as can be seen in Figure 5, we observe that in these cases the intonational movement following the focus is maintained at the same level, without a low nuclear configuration, that is $! \mathrm{H}^{*} \mathrm{~L} \% / \mathrm{M} \%$. This flat pattern can be described as a "loss of prominence" or "de-emphasis", in contrast with complete deaccenting. We thus conclude that this is the prosodic mechanism with which CMS signals post-focal given information (cf. Krifka, 2007), i.e. we conclude that this is the information structure equivalent in CMS of deaccenting in languages like English. In our data, duration and vowel quality are preserved in postfocal material, accompanied by sequences of monotonal accents. In addition, in some cases it is observed that the $! \mathrm{H}^{*}$ accents show a small rising, less than 1 semitone. This fact, coupled with the fact that in some cases the execution of the downward movement at the end of the utterance is not carried out completely (but is sustained), may be an indication that this phenomenon is perhaps akin to pitch compression (cf. Vanrell \& Fernández Soriano, 2018, for European Spanish, and Frota et al., 2015, for Portuguese).

\subsection{Phrasing}

Although our study does not show conclusively that prosodic binarity is the primary factor regulating phonological phrasing in CMS, our results nonetheless clearly show that phonological phrasing is not primarily regulated by syntactic constituency.

We further observe that in the large majority of cases, if an utterance ends with a PP, the PP forms its own phonological phrase, as in Figures 5 and 6, which is reported also in Prieto (2006). This turned out to be independent of (a) whether the PP is binary (i.e. de Diego Luna, 'of Diego Luna') or not (i.e. del potrillo, 'of the stallion'); (b) whether the PP corresponds or not to the focus of the utterance, and; (c) whether the PP is embedded directly under the VP, or if it is embedded in a DP. Once again, this is an unexpected result under the syntactic approach to phonological phrasing.

These results instead appear to indicate that binarity has some effect on the formation of phonological phrases in these data. Although (as mentioned) utterance-final PPs most frequently form their own phonological phrase irrespective of any other consideration, the patterns in (1) and figure 6 appear to follow the binarity requirement expected under the prosodic approach to phonological phrasing. Hence the first two phonological phrases in this case are constituted each by two prosodic words. In this respect, once again it is worth highlighting that the first phonological phrase groups the subject and verb together, a pattern that does not follow any of the syntactic constituency relations in the sentence. Although we observe that the evidence for binarity is much less clear once we consider the patterns of phonological phrasing in focused VPs, it is still worth mentioning that at least the data from focused direct objects point to the conclusion that binarity has some effect on the formation of phonological phrases, whereas evidence of syntactic constituency playing a similar role is less frequent in our results.

Interestingly syntactic constituency does appear to be the primary factor regulating phrasing when the verb and a nonbranching or single branching direct object are the only constituents in the VP of subordinate clauses (as in Table 3). However, overall this ceases to be the case when the VP is structurally more complex: double branching of the direct object, utterance final adjunct PPs, and complement clauses embedded in the VP, all contribute to the VP being mapped into two or more $\phi P s$. 


\section{CONCLUSIONS}

In this paper we have presented the results of a reading task test designed to investigate the prosodic properties of information focus in Central Mexican Spanish. Our study reveals a number of previously undocumented properties of this variety of Spanish, and further sheds light on the debate on whether phonological phrasing in Spanish is primarily regulated by prosodic or syntactic considerations. With respect to pitch accents, our study confirms the realization of the $\mathrm{L}+\mathrm{H}^{*}$ accent as a mark of information focus, but we register the monotonal accents ! $\mathrm{H}^{*}$ and $\mathrm{L}^{*}$ more frequently for this function. As such, we observe that the association between the $\mathrm{L}+\mathrm{H}^{*}$ pitch accent and information focus is not absolute across varieties of Spanish. Furthermore, in many cases we observe that the pitch accent is not the only mechanism used to signal the focus: this is because we observe the presence of prosodic edges to the left of the focus, presumably functioning as an additional prosodic cue to identify it.

In the case of in situ foci, in our results we do not observe deaccenting of post-focal material; instead we observe a sequence of non-rising forms (a flat pattern). In terms of information structure, this pattern without prominent forms, which we describe as "de-emphasis", presumably signals in Central Mexican Spanish the same kind of given information that is characteristically deaccented in languages like English. Lastly, with respect to phonological phrasing, our results confirm the results reported in Prieto (2006), versus those of D'Imperio et al. (2005). Specifically, we observe no absolute correspondence between the VP and a single $\phi P$. Double branching of the direct object, utterance final adjunct PPs, and complement clauses embedded in the VP, all contribute to the VP being mapped into two or more $\phi P$ s. We also observed that there are striking differences between the phrasing patterns of focused matrix VPs in simple clauses, focused matrix VPs in complex clauses, and focused subordinate VPs.

\section{REFERENCES}

Alinear Feldhausen, I. (2016). Inter-speaker variation, Optimality Theory and the prosody of clitic left-dislocations in Spanish. Probus, 28, 293-334. http://dx.doi.org/10.1515/ probus-2015-0005.

Armstrong, M. E. (2010). Puerto Rican Spanish intonation. In P. Prieto \& P. Roseano (Eds.), Transcription of Intonation of the Spanish Language (pp. 155-190). Münich: Lincom.

Beckman, M., Díaz-Campos, M., Mcgory J.T \& Morgan T.A. (2002). Intonation across Spanish, in the tones and break indices framework. Probus, 14(1), 9-36. http://dx.doi.org/ $10.1515 /$ prbs. 2002.008

Cruttenden, A. (1993). The de-accenting and re-accenting of repeated lexical items. In D. House \& P. Touati (Eds.), Proceedings of an ESCA Workshop on Prosody, Working Papers 41 (pp. 16-19). University of Lund: Department of Linguistics and Phonetics.

De-la-Mota, C., Martín Butragueño, P., \& Prieto, P. (2010). Mexican Spanish Intonation. In P. Prieto \& P. Roseano
(Eds.), Transcription of Intonation of the Spanish Language (pp. 319-350). Munich: Lincom Europa.

D’Imperio, M., Elordieta, G., Frota, S., Prieto, P. \& Vigario, M. (2005). Intonational phrasing in Romance: The role of syntactic and prosodic structure. In S. Frota, M. Vigario \& M. J. Freitas (Eds.), Prosodies (pp. 59-98). The Hague: Mouton de Gruyter.

Downing, L. J. \& Rialland, A. (2017). Introduction. In L. J. Downing \& A. Rialland (Eds.), Intonation in African Tone Languages (pp. 1-16). Berlin: De Gruyter Mouton.

Elordieta, G., Frota, S. \& Vigário, M. (2005). Subjects, objects and intonational phrasing in Spanish and Portuguese. Studia Linguistica, 59, 110-143. http://dx.doi. org/10.1111/j.1467-9582.2005.00123.x

Estebas Vilaplana, E. \& Prieto, P. (2008). La notación prosódica del español: Una revisión del Sp_ToBI. Estudios de Fonética Experimental, 17, 263-283.

Face, T. (2002). El foco y la altura tonal en español. Boletín de Lingüística, 17, 30-52.

Feldhausen, I., Pešková, A., Kireva, E. \& Gabriel, C. (2011). Categorical perception of Porteño nuclear accents. In W. Lee \& E. Zee (Eds.), Proceedings of the 17th International Congress of Phonetic Sciences (ICPhS XVII) (pp. 116119), Hong Kong, 17-21. August 2011.

Feldhausen, I. \& Lausecker, A. (2018). Diatopic variation in prosody: Left- and right-dislocations in Spanish. In M. Belz, S. Fuchs, S. Jannedy, C. Mooshammer, O. Rasskazova \& M. Zygis (Eds.). Proceedings of Phonetics and Phonology in the German-Speaking Countries 13, 57-60.

Féry, C. (2017). Intonation and Prosodic Structure. Cambridge: Cambridge University Press.

Frota, S., Cruz, M., Svartman, F., Collischonn, G., Fonseca, A., Serra, C., Oliveira, P. \& Vigário, M. (2015). Intonational variation in Portuguese: European and Brazilian varieties. In S. Frota \& P. Prieto (Eds.), Intonational Variation in Romance (pp. 235-283). Oxford: Oxford University Press.

Frota, S. \& Vigário, M. (2018). Syntax-Phonology interface. In M. Aronoff (Ed.), Oxford Research Encyclopedia of Linguistics. Oxford: Oxford University Press. http://dx.doi. org/10.1093/acrefore/9780199384655.013.111

Gabriel, C. (2010). On focus, prosody, and word order in Argentinean Spanish: A minimalist OT account. Revista Virtual de Estudos da Linguagem. Special edition no. 4.

Gabriel, C., Feldhausen, I. \& Pešková, A. (2011). Fraseo prosódico en español porteño. In C. Gabriel \& C. Lleó (Eds.), Intonational Phrasing in Romance and Germanic (pp. 153-182). Amsterdam/Philadelphia: John Benjamins Publishing Company.

Gabriel, C., Feldhausen, I., Pešková, A., Colantoni, L., Lee, S., Arana, V. \& Labastía, L. (2010). Argentinian Spanish intonation. In P. Prieto \& P. Roseano (Eds.), Transcription of Intonation of the Spanish Language (pp. 285-318). Munich: Lincom Europa.

Ghini, M. (1993). Ø-formation in Italian: A new proposal. In C. Dyck (Ed.), Toronto Working Papers in Linguistics, 12(2). Toronto: Department of Linguistics, University of Toronto. 41-78.

Hoot, B. (2016). Narrow presentational focus in Mexican Spanish: Experimental evidence. Probus, 28, 335-365. http://dx.doi.org/10.1515/probus-2014-0004

Hualde, J. I. (2014). Los sonidos del español. Cambridge: Cambridge University Press.

Hualde, J. I. \& Prieto, P. (2015). Intonational variation in Spanish: European and American varieties. In S. Frota \& P. Prieto (Eds.), Intonational Variation in Romance (pp. 350-391). Oxford: Oxford University Press.

Ito, J. \& Mester, A. (2012). Recursive prosodic phrasing in Japanese. In T. Borowsky, S. Kawahara, T. Shinya \& M. Sugahara (Eds.), Prosody Matters: Essays in Honor of Elisabeth Selkirk (pp. 280-303). London: Equinox.

Jun, S.-A. (2014). Prosodic typology: By prominence type, word prosody, and macro-rhythm. In Sun-Ah Jun (Ed.), Prosodic Typology II. The Phonology of Intonation and Phrasing (pp. 520-539). Oxford: Oxford University Press. http://dx.doi. org/10.1093/acprof:oso/9780199567300.003.0017 
Kim, S. \& Avelino, H. (2003). An intonational study of focus and word order variation in Mexican Spanish. In E. Herrera \& P. Martín Butragueño (Eds.), La tonía: Dimensiones fonéticas y fonológicas (pp. 357-374). Mexico City: El Colegio de México.

Krifka, M. (2007). Basic notions of information structure. In C. Fery \& M. Krifka (Eds.), Interdisciplinary Studies of Information Structure 6, pp. 13-55. http://dx.doi. org/10.1556/ALing.55.2008.3-4.2

Ladd, D. R. (2008). Intonational Phonology. Cambridge: Cambridge University Press.

Martín Butragueño, P. (2011). La estratificación sociolingüística de la entonación circunfleja mexicana. In P. Martín Butragueño (Ed.), Realismo en el análisis de corpus orales (pp. 93-121). Mexico City: El Colegio de México.

Martín Butragueño, P. (2019). Fonología variable del español de México. Vol. II: Prosodia enunciativa (tomo 1). Mexico City: El Colegio de México.

Martín Butragueño, P. (forthcoming). Fonología variable del español de México. Vol. II: Prosodia enunciativa (tomo 2). Mexico City: El Colegio de México.

Martín Butragueño, P. \& Mendoza, E. (2018). Prosodic nuclear patterns in narrow and broad focus utterances: Pragmatic and social factors in Central Mexican Spanish. In M. Uth \& M. García (Eds.), Focus Realization and Interpretation in Romance and Beyond (pp. 131-172). Amsterdam/Philadelphia: John Benjamins. http://dx.doi. org/10.1075/slcs.201.05mar

Murrieta, L. (2016). Análisis experimental del umbral de percepción entonativa en el español del centro de México. Honors Thesis. Mexico City: Universidad Nacional Autónoma de México.

Nespor, M., \& Vogel, I. (1986). Prosodic Phonology. Dordrecht: Foris.

Pamies, A., Fernández Planas, A. M., Martínez Celdrán, E., Ortega, A. \& Amorós M. (2001). Umbrales tonales en español peninsular. In M. Cuenca Vallain (Ed.), Actas del II Congreso Nacional de Fonética Experimental (pp. 272278). Sevilla: Universidad de Sevilla.

Polo, N. \& Elordieta G. (2016) Evidencia segmental del sintagma fonológico en español. Lingüística Española Actual, 38(1), 43-67.

Prieto, P. (2006). Phonological phrasing in Spanish. In S. Colina \& F. Martínez-Gil (Eds.), Optimality-Theoretic Advances in Spanish Phonology (pp. 39-61). Amsterdam \& Philadelphia: John Benjamins. http://dx.doi.org/10.1075/ la.99.03pri

Prieto, P. \& Roseano, P. (Eds.) (2010). Transcription of Intonation of the Spanish Language. Munich: Lincom Europa.

Selkirk, E. (1995). Sentence prosody: Intonation, stress and phrasing. In J. Goldsmith (Ed.), The Handbook of Phonological Theory (pp. 550-569). Oxford: Blackwell.

Selkirk, E. (2011). The syntax-phonology interface. In J. A. Goldsmith, J. Riggle \& A. C. L. Yu (Eds.), The Handbook of Phonological Theory, 2nd. ed. (pp. 425484). Oxford: Blackwell Publishing. http://dx.doi. org/10.1002/9781444343069.ch14

Truckenbrodt, H. (1999). On the relation between syntactic phrases and phonological phrases. Linguistic Inquiry, 30, 219-255. http://dx.doi. org/10.1162/002438999554048

Vanrell, M. \& Fernández-Soriano, O. (2018). Language variation at the prosody-syntax interface: Focus in European Spanish. In M. Uth \& M. García (Eds.), Focus Realization and Interpretation in Romance and Beyond (pp. 33-70). Amsterdam/Philadelphia: John Benjamins.

Villalobos, L. (forthcoming). Prosodia de la expresión temprana del foco informativo y del foco contrastivo en español. Doctoral dissertation, Mexico City: Universidad Nacional Autónoma de México.

Welby, P. (2003). CreaFigures Script.praat [modified in 2009 by Rafèu Sichel-Bazin]. 


\section{APPENDIX}

Information focus (the brackets were not shown to the participants, they are only included here for reference).

(1)

a. ¿Qué hizo Mario?

Mario [lavó los platos grandes en la cocina]

b. ¿Qué lavó Mario?

Mario lavó [los platos grandes] en la cocina

c. ¿Qué platos lavó Mario?

Mario lavó los platos [grandes] en la cocina

d. ¿Qué hizo Mario en la cocina?

Mario [lavó los platos grandes] en la cocina

e. ¿Dónde lavó Mario los platos grandes?

Mario lavó los platos grandes [en la cocina]

(2)

a. ¿Qué hizo Ana?

Ana [vio la nueva película de Diego Luna]

b. ¿Qué vio Ana?

Ana vio [la nueva película de Diego Luna]

c. Ana ¿Qué vio de Diego Luna?

Ana vio [la nueva película] de Diego Luna

d. Ana ¿Qué película vio de Diego Luna?

Ana vio [la nueva] película de Diego Luna

e. Ana ¿De quién vio la nueva película?

Ana vio la nueva película [de Diego Luna]

(3)

a. ¿Qué hizo Marina?

Marina [lavó la piel negra del potrillo]

b. ¿Qué lavó Marina?

Marina lavó [la piel negra del potrillo]

c. Marina ¿qué parte de la piel del potrillo lavó?

Marina lavó la piel [negra] del potrillo

d. Marina ¿qué es lo que lavó del potrillo?

Marina lavó [la piel negra] del potrillo

e. Marina ¿de quién lavó la piel negra?

Marina lavó la piel negra [del potrillo]

(4)

a. ¿Qué hizo Juan?

Juan [dijo que María tiene un abrigo amarillo]

b. ¿Qué dijo Juan?

Juan dijo que [María tiene un abrigo amarillo]

c. ¿Qué dijo Juan de María?

Juan dijo que María [tiene un abrigo amarillo]

d. ¿Qué dijo Juan que tiene María?

Juan dijo que María tiene [un abrigo amarillo]

e. ¿De qué color es el abrigo que Juan dice que tiene

María?

Juan dijo que María tiene un abrigo [amarillo]

f. Juan ¿de quién dijo que tiene un abrigo amarillo?

Juan dijo que [María] tiene un abrigo amarillo

g. ¿Qué ropa amarilla dijo Juan que tiene María?

Juan dijo que María tiene [un abrigo] amarillo
(5)

a. ¿Qué pasa con Manuel?

Manuel [cree que el perro de Juan es blanco]

b. ¿Qué cree Manuel?

Manuel cree [que el perro de Juan es blanco]

c. ¿Qué cree Manuel del perro de Juan?

Manuel cree que el perro de Juan es [blanco]

d. ¿De quién cree Manuel que su perro es blanco?

Manuel cree que el perro [de Juan] es blanco

(6)

a. ¿Qué hizo María?

María [vio que Luis se fue a casa de Antonio]

b. ¿Qué vio María?

María vio [que Luis se fue a casa de Antonio]

c. ¿A dónde vio María que se fue Luis?

María vio que Luis se fue [a casa de Antonio]

d. María ¿A quién vio que se fue a casa de Antonio?

María vio que [Luis] se fue a casa de Antonio

e. ¿A casa de quién vio María que se fue Luis?

María vio que Luis se fue a casa de [Antonio] 